\title{
The Gambia
}

National Cancer Institute

\section{Source}

National Cancer Institute. The Gambia. NCI Thesaurus. Code C16598.

A country in western Africa, bordering the North Atlantic Ocean and surrounded by Senegal. 